Satu 0jala, postdoctoral researcher, satu.ojala@ uta.fi

Jouko Nätti, professor

Liudmila Lipiäinen, statistician

Faculty of Social Sciences, University of Tampere, 20.3.2017

\title{
Types of temporary employment: an eight-year follow-up of labour market attachment
}

\section{Introduction}

This study focuses on the long-term labour market attachment of temporary employees in Finland. Employees with a temporary contract account for $15 \%$ of the EU-28 workforce. The figure in Finland is slightly higher at 17\% (Eurostat 2016). It is an implicit assumption in the literature about 'atypical' employment that non-standard is necessarily substandard (Broschak et al. 2008), that working conditions in these jobs are poorer than in regular employment.

However, here is great heterogeneity in the conditions of temporary employment that warrants closer attention (Aronsson et al. 2002; Booth et al. 2002). There is also a shortage of long-term follow-ups to monitor temporary employees' later labour market attachment (Kalleberg 2012). In this article, we explore how different types of temporary employment are associated with labour market transitions in an eight-year follow-up. The combination of representative quality of work life surveys from 1990, 1997 and 2003, and merged register data on Finnish employees allows us to analyse different subgroups of temporary employees and later labour market outcomes.

O ur approach allows us to combine an analysis of the baseline heterogeneity of temporary employees which at once indicates their initial core-periphery position (Aronsson et al. 2002) - with an examination of these employees' future transitions in order to gain a clearer view of how different types of temporary work are associated with more stable or unstable labour market attachment. We analyse temporary employees' attachment to employment in the following eight years to see how temporary employees' subgroups are distributed between different transition cluster groups, as compared with permanent employees. We are able to bring a more multi-faceted view on different outcomes of temporary employees' later employment and estimate to what degree their paths are becoming either increasingly stabilised or fragmented. We contribute to labour market segmentation theory and bring longitudinal evidence to the discussions on employment insecurity and job polarisation (Barbieri 2009; Kalleberg 2012; Marchington et al. 2005; Saloniemi and Zeytinoglu 2007).

\section{Previous literature}

Labour market outcomes of temporary employment are usually approached from the vantage point of labour market segmentation, job quality ('good-job' vs. 'bad-job' typology), precariousness and contingency of the employment conditions (Kalleberg 2012). Labour market segmentation theory 
argues that the labour market is divided into primary (high-skilled, secure, good quality) and secondary (low-skilled, displaceable, low quality) segments. Temporary jobs are intuitively thought to be part of the secondary segment. Analyses of the heterogeneity of temporary employment have also used another similar theory that is the core-periphery model of the labour market (A ronsson et al. 2002), according to which the conditions and quality of different types of atypical jobs are spread out across a coreperiphery axis. Close to the core of this axis, working conditions approximate those of permanent employees. It seems that highly-skilled temporary project workers in particular have similar working conditions to permanent employees (primary segment, core employment), whereas seasonal-casual workers, on-call workers or temporary agency workers lie far away on the periphery (Aronsson et al. 2002; Booth et al. 2002; Kompier et al. 2009).

Empirical analyses of temporary and other forms of non-standard employment have found that the outcomes of certain types of employment are further stratified by age, gender, education, previous unemployment, immigration status, task complexity and skills achieved for example through employerprovided training, as well as by economic cycles, local labour market features and national contexts (Barbieri 2009; Cutuli and Guetto 2012; de Vries and Wolbers 2005; Fervers and Schwander 2015; Fuller and Vosko 2008; $G$ ash 2008; G ebel 2010; Kahn 2016; Reichelt 2015).

Another conceptual approach elaborating temporary jobs is concerned to test 'stepping-stone'/ 'bridge employment'/ 'integration' hypotheses as opposed to 'trap' hypotheses. These are used to assess whether temporary employment is a way of entering standard employment, or whether it is associated with exclusion from the labour market and unemployment (e.g. G ash 2008). The bridge employment theory suggests that employers initially prefer to hire employees on a temporary or 'trial' basis before signing a permanent contract (see $G$ ash 2008; G ebel 2010). From a wider labour market point of view, temporary and other forms of non-standard employment can be seen as forming part of transitional labour markets that create work opportunities through flexible uses of labour (Schmid 2008). These bridge theories lie at the core of EU active labour market policy schemes, which stress that every job opportunity is better than unemployment, and that therefore more jobs should be created through more flexible labour usage.

The trap argument, by contrast, argues that temporary employment does nothing to facilitate upward mobility. Employers use temporary labour only as a stop-gap in situations of cyclical high demand or staff shortages (e.g. G ash 2008; Scherer 2009; Steijn et al. 2006). The argument ties in with labour market segmentation theory in that it assumes no mobility between separate segments of the labour force: once marginalised, always marginalised.

There are some earlier empirical studies of the long-term labour market attachment of fixed-term contract holders. These analyses have focused on wages, health, country and employment regime differences, as well as on transitions between unemployment, temporary employment and permanency, or on a mix of these outcomes. Given the limited amount of longitudinal evidence in the field, we shortly reflect on all these issues.

First, concerning pay, earlier findings suggest that for those in temporary positions there will be a negative effect of job instability on income. Fuller and Stecy-Hildebrandt (2014) found that Canadian temporary workers had lower earnings than permanent workers, both at the start and the end of a fiveyear follow-up. Elia (2010) found an increasing wage penalty for Italian fixed-term employees from 2002 to 2006, following a policy change in 2003 that eased the conditions for the use of temporary 
contracts. A few longer-term follow-ups have shown signs of convergence in pay between employees in permanent and fixed-term positions. Convergence, in principle, necessitates higher skills. The probability of crossing the bridge to earning similar wages as those earned by permanent employees is improved if employees gain a higher education (G ebel 2010), if they are young (Steijn et al. 2006), if they receive training from their employers ( $\mathrm{Kahn} 2016$ ), or if the quality of their temporary contract is closer to core employment (fixed-term, as opposed to seasonal-casual, Booth et al. 2002).

Second, there is a broad literature evaluating the relationship between temporary jobs and health, with unclear findings (see D awson et al. 2015; Wagenaar et al. 2012 for discussion). Liukkonen (2012) found evidence of negative intertwining effects between employment type and health especially among those in the most peripheral labour market positions (atypical employment relationships, unemployment) as compared to employees in common fixed-term or permanent positions. She also found that, in a fouryear follow-up, poorer self-rated health at the baseline of follow-up was associated with a more unstable career trajectory, but that also temporary employment in the beginning, when followed by a fragmented work career, tended to increase psychological symptoms. An increased sense of coherence, on the other hand, predicted more stable employment patterns. In Wagenaar et al. (2012), lower general health as well as higher emotional exhaustion were associated with downward employment trajectories among permanent employees, whereas temporary employees with higher work dedication and better work ability more probably gained permanency. In Kompier et al. (2009), transitions that included better contracts were related to better quality jobs as well as improved psychological health. According to D awson et al. (2015), the risk of transition into a temporary position increased among permanent workers with mental health problems, however this was mediated by job dissatisfaction in that unhappy employees themselves selected a non-permanent, new job. The finding requires that health research takes into account not only the type of employment contract, but also job quality.

Third, country and employment labour regimes are highly significant to labour market attachment. Fervers and Schwander (2015) reported that more liberal (and thus more flexible) employment regimes such as the UK had larger numbers of young temporary workers who were able to step into a better labour market position. They observed that an 'outsider' position is deeply affected by employment protection levels in the country: Spanish and G reek temporary workers had a much higher risk of unemployment than Austrian and British temporary workers. This conclusion is supported by Elia (2010), who found deepening polarisation between employees in temporary and permanent positions after deregulation in Italian labour law in 2003. In a comparison of four countries - France, West G ermany, Britain and D enmark - G ash (2008) found that temporary work was most likely to offer a route to permanent employment in Germany. Equally important was the composition of the labour force in the country: French temporary workers in particular were less educated and in a weaker and therefore more insecure position.

Fourth, only few earlier studies have examined labour market transitions following temporary employment, the theme that is our focus here. It has been shown that even short-term employment increases the probability of gaining more stable employment (Kyyrä 2008). Among younger, bettereducated employees and those with no previous unemployment, a temporary contract may serve as a stepping stone into permanent employment (Fang and MacPhail 2008; G ash 2008; Gebel 2010; Reichelt 2015). In the Netherlands (Steijn et al. 2006) it was found that among young workers, a period of unemployment at the beginning of the work career is linked with weaker labour market attachment, 
whereas the negative effect of employment starting with a temporary contract disappeared in the long term.

Longitudinal analyses of the heterogeneous types of temporary employment have been presented by Booth et al. (2002) for Britain and by Kompier et al. (2009) for the Netherlands. Kompier et al. (2009) found some evidence that linked lower job quality at the baseline with downward employment mobility (step into temporary agency/ on-call work). In the study by Booth et al. (2002), transitions from seasonal-casual temporary employment into permanency were rarer in the case of part-time work or public sector women. Among men, transitions to permanency were more frequent for those who had common fixed-term contracts than for employees with seasonal-casual contracts. As for wages, Booth et al. (2002) found a stronger wage 'penalty' among full-time seasonal-casual workers as compared with fixed-term contract holders. Furthermore, the penalty of fixed-term contract decreased in a ten-year follow-up, which was not the case for seasonal-casual workers.

O verall, earlier research on the labour market outcomes of temporary work have approached temporary work mainly from the point of view of labour market segmentation or the bridge or trap hypothesis. The vast majority of empirical studies on the consequences of temporary work have used cross-sectional data or relatively short-term follow-up data. Much less focus has been given to the longterm labour market attachment of fixed-term contract holders. Furthermore, most studies have failed to take into account the different subgroups of temporary workers. In this article, we use a labour market segmentation approach to study the long-term labour market attachment of different subgroups of temporary workers.

\section{Aims}

The first aim of our study is to construct different types of temporary work, which will allow us to take into account the heterogeneity of temporary work. O ur classification is based on the distinction proposed by Aronsson et al. (2002) between the core and periphery groups of temporary workers.

O ur second aim is to construct a typology of labour market attachment during the 8-year register-based follow-up period. Whereas earlier studies have focused on temporary employees' transitions between unemployment, temporary and permanent work, we take a broader view and analyse employees' entry into or switches between employment, unemployment and studying or moving to a position outside the labour market or different types of pension statuses.

O ur third and main aim is to examine the association between type of temporary work and later labour market attachment. Earlier evidence of temporary workers' labour market attachment later in life is mixed. It seems that temporary employment involves greater labour market risks when working conditions are more peripheral (e.g. seasonal work). Based on earlier studies (Aronsson et al. 2002; Booth et al. 2002) we hypothesise that temporary employees with a peripheral type of contract will have a more fragmented career with spells of unemployment, or they may leave the labour market during the follow-up. Second, we hypothesise that employees closer to 'core' employment, especially those in 'common fixed-term employment' will increasingly stabilise their employment position during the follow-up. 


\section{Data and Measures}

\subsection{D ata}

In order to construct different types of temporary work we use representative data from the Finnish Q uality of Work Life Surveys (FQ WLS) collected by Statistics Finland in 1990, 1997 and 2003. These are cross-sectional studies collected every six years since the 1970s, with a very high response rate (68$89 \%$ ), involving between 3,000 and 5,000 people and covering the entire wage and salary earning population residing in Finland at each point of time. The surveys are conducted in the form of personal face-to-face interviews that last on average a little over an hour (Sutela and Lehto 2014). We chose to focus on employees aged 20-54 because they were not due to retire on old-age pension during the follow-up. The data from 1990, 1997 and 2003 were pooled for the analysis and comprised a total of 9,255 respondents.

For the construction of a typology of later labour market attachment we use register-based follow-up data merged with each of the above-mentioned survey datasets. The register data is based on population statistics gathered by Statistics Finland and it was merged with survey data for each individual. We chose to restrict the follow-up period after each survey year to eight years. The reason for this was that for the most recent dataset (2003), we only have register information until 2011. Register data includes information on each respondent's annual main activity, which will be evaluated with sequence analysis (employed, not employed, outside labour market) at the end of each follow-up year after the reference year (survey 1990 + register 1991-1998, 1997 + 1998-2005, 2003 + 20042011). O ne restriction is that we are unable to follow changes in employment contract type over time. Instead, we compare baseline contract type and the register data on annual main activities that refer to the surveyed employees' later labour market statuses.

\subsection{A nalysis methods}

D escriptive analysis of the comparison group characteristics was based on cross tabulation with $\chi^{2}$-test (with adjusted residuals for pairwise comparisons) and one-way analysis of variance with F-test. Later labour market attachment clusters are constructed with sequence analysis, which is described in more detail in section 5.3. The association between type of temporary work and labour market attachment is examined with multinomial logistic regression analysis. In multinomial logistic regression analysis, the most common sequence cluster (stable employment) was used as the reference group. We first built a model adjusted for the type of employment contract and survey year. In the second model, we adjusted for factors that according to earlier research are associated with temporary employment. These include demographic characteristics as well as job and labour market controls. The results are presented as Relative Risk Ratios (RRR). In this model a reference group (permanent contract) is chosen for the categorised independent variable (temporary contract type). The reference group gets the odds ratio value of 1.0 and other groups are compared to this. The RRR indicates an increase $(>1.0)$ or decrease $(<1.0)$ in the relative risk of entering the specified sequence cluster compared to the reference group (1.0).

\subsection{Independent variable: type of temporary work}

The distinction between temporary and permanent employment is based on survey data and self-report (subjective classification), i.e. a direct question on whether the respondent is in fixed-term employment as opposed to an employment contract that is 'valid until further notice'. Type of temporary 
employment is then inquired among temporary workers with the following pre-set response options: Substitute without a permanent post, On a trial period, Hired with employment subsidies, D oing seasonal work, Come to work only when summoned (on-call), In apprenticeship training, and In other fixed-term employment relationship. For the analysis we constructed three subgroups of temporary work. The number of respondents in each survey and the sizes of temporary employees' subgroups as a proportion of all employees are described in Table 1.

Table 1. Contrad types of employes aged 20- 54 according to year of survey, FQ W L S 1990, 1997 and 2003

In 1990- 2003 the most common types of temporary employment were 'Substitutes' (group 1) and a category that reflects 'Common fixed-term employment' (group 2) (Table 1). Unfortunately, more detailed information on the content of this latter category was only available from 2003 onwards. Based on the 2003 survey we know that the major categories in this Common fixed-term group are project workers, workers with discontinuous financing, employees temporarily assigned to a vacant post and employees in otherwise fixed-tem positions (altogether three fifths of the group). The smaller categories include employees whose employer does not want to establish a permanent post, unqualified employees, and teachers with short working hours. In addition, we included in this second comparative group those on a trial period and in apprenticeship training. All in all, employees in this group 'Common fixed-term employment' have a higher than average education and higher-quality jobs than other temporary workers (Table 2; Ojala et al. 2015). The remaining temporary employees were combined into the third group that is characterised by more peripheral employment conditions (Seasonal, On-call, Temporary agency workers, Employed with subsidies) and named here as 'Periphery fixed-term employment', following the theorisation by Aronsson et al. (2002). Employees with a permanent contract were defined as the fourth (reference) group.

\subsection{D ependent variable: labour mark et sequence cluster during the follow-up period}

Transitions between each year's main activities were examined, first, using sequence analysis. Main activity is used as the examined variable and it included eight statuses: student, employed, unemployed, disability pension, unemployment pension, other early pension, old age pension, and other activity.

In this analysis, a sequence is defined as a list of elements ordered over time for a given individual where every element represents a certain status (Abbott 1995; A isenbrey and Fasang 2010; BrzinskyFay et al. 2006; G authier et al. 2010). First, the dissimilarities between each sequence were computed. Several different algorithms and methods with different indelcosts were applied to calculate distances between individual sequences. The similarity of sequences is high when only a few elements have to be replaced, inserted, or deleted in one sequence to arrive at another sequence (Biemann and D atta 2014). Then, individuals were clustered into groups of clusters with similar transition histories based on the distances between individual sequences (Figure 1). D uring clustering, a tree of sequences was constructed. D ifferent cluster solutions with one to ten cluster groups were represented graphically, and the solutions with more or less clusters were compared. We used TraMineR library in R for sequence analysis (Studer et al. 2011). The Optimal Matching Algorithm (OMA) with Ward clustering method provided the best suitable clustering of our data. The quality of a clustering was measured using the measure 'Average Silhouette Width' as proposed by Kaufman and Rousseeuw (1990). In our case A SW measure 0.6769 indicated the most reasonable structure for six clusters. This six-cluster solution was then used as the dependent variable in the second, main part of the analysis, using multinomial logistic regression analysis. 


\subsection{C ontrol factors}

Control factors in the multinomial logistic regression analysis included demographic characteristics as well as job and labour market controls. Background factors included gender, age, children, studies and education. G ender is a central denominator in temporary employment in Finland (Table 2, Eurostat 2016). In our follow-up, which includes a sequence group with increased labour market absences, it is important to control for whether the respondent has a child (under 18 yrs.), or whether a new baby is born during the follow-up.

Age served as another important control (e.g. Fang and MacPhail 2008; Steijn et al. 2006). Age and duration of employment spell correlated at the level 0.6. To avoid too high multicollinearity with the duration of job contract, we included a dummy variable for age, separating younger ( $<33$ yrs) and older workers (33-54 yrs, see Appendix for correlations). We also controlled for ongoing studies, i.e. whether the employee studied while working (see Table 2). Earlier research has consistently shown that higher education increases the probability that a temporary contract will act as a bridge to permanency, rather than as a trap (e.g. de Vries and Wolbers 2005; Steijn et al. 2006). We therefore controlled for education (basic, middle, tertiary).

Job quality includes wage level, job insecurity and personnel training. Earlier studies indicate that job quality is affected by employment conditions (Kahn 2016; Kompier et al. 2009; Reichelt 2015). Therefore, we take into account the most important job quality measures concerning temporary employees' labour market position. Based on the previous literature (Barbieri 2009; Cutuli and G uetto 2012; G ash 2008; G ebel 2010; Kahn 2016; Reichelt 2015), these are lower wages compared with permanent employees ('wage-penalty', Kahn 2016), increased threat of unemployment, and lower incidence of on-the-job training. We control for wages with standardised wage measures (originally 10 15 classes in surveys for employees' pay level). The measure for job insecurity includes fear of becoming unemployed, being dismissed or laid off (sum variable threats, Cronbach's alpha .804). Employer-provided training is measured with the employees' estimation of number of training days during the last 12 months.

Labour market position includes earlier unemployment experiences, earlier employment months, health, sector, region and survey year. It is known that earlier experience of unemployment affects labour market attachment in the future, a risk that increases with the length of the unemployment period (Steijn et al. 2006). To control baseline labour market position, we controlled for employed months in year -1 before the survey (0-12 months, picked from the register data), as well as self-report of at least one unemployment spell during the past five years (survey data). Furthermore, as health is intertwined with more vulnerable labour market segment positions (D awson et al. 2015; Kompier et al. 2009; Liukkonen 2012; Wagenaar et al. 2012), we adjusted for long-term illnesses (self-report in survey data).

Furthermore, we consider sector of employment (private/ public) as a key structural characteristic of the job, since temporary contracts are very common in the Finnish public sector and in femaledominated branches in particular. We also control for place of residence in Finland, as the labour markets are regionally divided between growing cities (predominantly urban south-west) and more or less declining rural areas (northern and eastern parts of Finland). Another important structural control is year (1990, 1997, and 2003). The Finnish labour markets were severely affected by the deep recession that struck the economy in the 1990s. In the aftermath of that recession, the proportion of temporary 
contracts increased to one-fifth of all employment. Finland has also been affected by economic recession since 2008, although the employment rate has not fallen to the same extent as in the 1990s. There has been no increase in temporary employment during this more recent recession.

\section{Results}

\subsection{Characteristics of the comparison groups in survey data}

Table 2 shows the different characteristics of the comparison groups in the Finnish quality of work life surveys 1990, 1997 and 2003. D escriptive analysis of the comparison groups was based on cross tabulation with $\chi^{2}$-test (with adjusted residuals for pairwise comparisons) and one-way analysis of variance with F-test.

Table 2. Descriptives of temporary employes' subgroups by control factors, FQW L S 1990, 1997 and 2003

In Finland, temporary employment is more gender-polarised than in Europe on average (Eurostat 2016). This is due to the high participation of women in the labour force in public sector occupations, where temporary contracts are common (Table 2). This concentration of temporary employment in the public sector and among women is the reason we have included a separate fixed-term category 'Substitutes' in our analysis. Most substitute workers are women, and they typically work in health and social services. Large numbers of substitutes are needed not only due to sickness absences, but also because of the high frequency of parental leaves and periods of home-care among public sector workers (women with permanent vacancies). Furthermore, substitute workers themselves are more likely to have a baby during the follow-up period than employees on average (Table 2). Maternal leave in Finland is three months long, and most mothers choose to stay on for the six-month period of subsidised parental leave. Furthemore, the Finnish system of child home care allowance is intended for children under three, and has a very high coverage (Repo 2010). This further increases the need for substitute temporary workers.

Another distinctive characteristic of temporary employment in Finland is that large numbers of young people have temporary and/ or part-time jobs while they are studying (they account for one-fifth of common fixed-term workers, Table 2). It follows that temporary employees are somewhat younger than employees in permanent positions. However, both substitute workers and common fixed-term contract holders have a higher than average education, whereas employees with periphery-type contracts have a low education, have spent the shortest amount of time with the same employer (contract duration 0.8 yrs.), have lower wages, the lowest incidence of employer-provided training and very often have experiences of previous unemployment (85\%, Table 2). The vast majority of all temporary workers have experienced unemployment in the past five years, and their number of employed months the year before the survey are lower than average (Table 2).

Since the beginning of the 2000s, each year about one fourth of all employees in Finland have been in temporary employment and/ or had part-time contract (based on annual, cross-sectional Labour Force Survey statistics). Thus, on the one hand, the figure signifies a high overall share for flexible usage of Finnish labour (OSF 2015), attached to lower job quality: in temporary employees' groups, both wages and training days are at a lower-than-average level, and all of them suffer from significantly increased fear of losing their jobs (Table 2). On the other hand, Finnish employment conditions are secured by a high coverage of collective agreements and physically secured job conditions (Sutela and Lehto 2014). 
In sum, the majority of temporary jobs in Finland are not 'bad jobs' but more like bridges to better employment among younger people. However among a minority, the working conditions are poorer, associated with lower education levels, increased long-term illness, and earlier unemployment. According to Table 2, the group of periphery temporary employees have this kind of problematic labour market status.

\subsection{L abour mark et attachment sequence clusters: most employees have stable employment, minority face heterogeneous paths in or out}

A pplying sequence analysis to the register data, we then evaluated labour market transitions of all surveyed employees. We chose the solution with six clusters of transition histories in the eight-year follow-up (Figure 1 and Table 3). Cluster 1 'Stable employment' comprises those employees who were (more or less) consistently employed throughout the follow-up. The vast majority $(78 \%, n=7,159)$ of Finnish employees in 1990, 1997 and 2003 belong to this cluster. The second cluster $(2 \%, n=183$, 'O ut of labour market') is characterised by the largest number of sequences of 'other activity' outside the labour market, including short periods of unemployment (Figure 1). These employees probably include mothers of small children who have remained at home on parental leave or on home care allowances. The mean age (in the survey year) of the respondents in this cluster is 32 years, a typical age of having small children (Table 3).

Cluster 3 comprises 610 respondents (7\%) and is labelled 'Strengthening attachment'. This also includes young people (mean age 32 years) with periods of unemployment or studying during the follow-up, but who move into more permanent employment towands the end of the period under examination. The fourth cluster ( $\mathrm{n}=582,6 \%$, 'High unemployment') is characterised by vacillation between employment and unemployment early on, and even increasing unemployment during the follow-up (Figure 1). This cluster has the largest number of low-educated employees (Table 3).

Figure 1. Sequence clusters of yearly statuses of Finnish employed populations, FQ W L S 1990, 1997, 2003 + registers 8 yrs

The fifth and sixth clusters comprise employees gradually edging out of the labour market and with the highest mean age (46- 47 years, Table 3). The employees in the fifth cluster ( $\mathrm{n}=470,5 \%$ of all, 'Weakening attachment') are employed in the first years of follow-up, but they then begin to move onto heterogeneous paths out (unemployment pension, early, or old age pension). A small proportion of them also die during the follow-up (disappearance from the sequence graph). All of those slotted in the sixth cluster ( $\mathrm{n}=237,3 \%$, 'D isability pension') move to a disability pension sooner or later (Figure 1).

\subsection{A ssociation between type of temporary work and later labour mark et attachment}

D escriptive analysis of how the temporary workers' subgroups were divided between these clusters with cross-tabulation (Table 3) showed that none of these groups had a similar level of stable employment (cluster I) comparable to permanent contract holders in the following years. Four in five employees with permanent contracts were steadily employed over the next eight years, as compared to only two in five employees with periphery type contracts. Among substitute workers (typically women in the public sector), the corresponding figure was $70 \%$, and among common fixed-term workers $64 \%$.

Table 3. Break down of temporary work ers' subgroups into employment clusters, FQW L S 1990, 1997, 2003 + registers 8 yrs 
The good news is that $14-16 \%$ of temporary employees also showed increasing attachment to employment (cluster III): a total of $84 \%$ of substitute workers (clusters I and III combined), $80 \%$ of common fixed-term, and $56 \%$ of periphery contract holders either were in or found stable employment during the follow-up. Among permanent contract holders $86 \%$ had stable or increasingly stable employment (Table 3).

Meanwhile the bad news is that the position of temporary workers was associated with a strong unemployment risk. Especially the proportion of employees with periphery type contracts (29\%) was higher in Cluster IV 'High unemployment'. Substitute workers accounted for $8 \%$ of this cluster, and common fixed-term contract holders for $11 \%$, whereas no more than $5 \%$ of permanent contract holders were in the unemployment cluster. In addition, a larger share of temporary workers than permanent employees spent periods outside the labour market (cluster II) (Table 3). The most worrying finding of all, however, concerned the high risk of weakening attachment (cluster V) and disability pension (cluster VI) among employees with periphery contracts. They faced paths out of the labour market through different types of pensions and disability.

Finally, we performed multinomial logistic regression to find out whether there are statistically significant differences between temporary and permanent employees in terms of how they are divided between the sequence clusters and whether descriptive findings hold true when adjusting for the associated factors. We started with a model 1 that adjusts for type of employment contract and survey year of the pooled data (Table 4). Cluster I (stable employment) and permanent employment contract were used as a reference group. We found that the descriptive results above hold true even when controlling for the period of time (and especially the deep recession of the 1990s). All subgroups of temporary workers remained outside the labour market for some periods more often than permanent contract holders (cluster II), but it was also likely that they stabilised their work status in the near future (cluster III). At the same time the findings lend strong support to the hypothesis concerning employment fragmentation in that all subgroups of temporary workers had significantly higher odds ratios for belonging to the cluster of high unemployment (cluster IV). The group of temporary periphery workers (Relative Risk Ratio RRR 19.5) had the highest risk of being in this unemployment cluster. A gradual edging out of the labour market (clusters V and VI) was also more common among employees with periphery type contracts (RRR 2.5, and RRR 3.8, respectively) than among employees with permanent contracts and stable employment during the follow-up (Table 4).

Table 4. Multinomial logistic regression ceefficients by temporary employees' subgroups, dependent variable: employment sequence clusters, F Q W L S 1990, 1997, 2003 + registers 8 yrs

Next, we adjusted the model 2 for demographic, job and labour market characteristics (Table 4). For substitute workers and common fixed-terms, the risk of belonging to cluster II (out of the labour market) was practically lost. Instead, it was very probable (RRRs 1.9-2.1) that they gained increased attachment to employment (cluster III).

After adjusting for the aforementioned factors, substitute workers were not more likely to enter unemployment cluster IV. Thereby, after gaining more experience with increasing age, Finnish substitute workers, mainly working in the women-dominated public sector, are not in a particularly threatened labour market position. Meanwhile, those in common fixed-term employment were more likely to become unemployed, that is, were placed in cluster IV (high unemployment, RRR 1.7), as compared with employees with permanent contracts and cluster I. 
However, all heterogeneous future employment patterns (clusters II-VI) were more probable destinations for temporary periphery workers than for employees in permanent positions. The strongest risk ratios, however, were found for the most negative edging-out type of clusters V and VI. These employees were to become unemployed (cluster III, RRR 4.4) or pensioned off (to disability pension cluster VI, RRR 3.2; or to unemployment/ other type of pension in cluster V, RRR 3.3), even if earlier unemployment, long-term illness, education and job quality were adjusted for. This, alarmingly, suggested that the weakest and most vulnerable employee group in the baseline survey years - those who had failed to establish a stable labour market position but had periphery-type contracts - were even more likely to find themselves in a position of disability, persistent unemployment or early retirement during the following eight years.

\section{Discussion}

O ur analysis contributes to the emerging empirical understanding of how heterogeneous forms of temporary employment are associated with long-term labour market paths. First, we identified three groups of temporary workers based on type of temporary contract: substitute, common fixed-term (typically project workers), and temporary periphery workers including on-call, employment subsidy, temporary agency and seasonal workers. O ur classification was based on the distinction proposed by Aronsson et al. (2002) between the core and periphery groups of temporary workers. Earlier studies of temporary work have rarely been able to use this kind of typology (see Booth et al. 2002; Kompier et al. 2009; Wagenaar et al. 2012). A nother way of grouping temporary workers is based on the motivation of temporary work (voluntary and involuntary temporary workers, e.g. Kauhanen and Nätti 2014)).

Second, we examined transitions between employment and other activities in an eight-year follow-up based on sequence analysis of main activity in each follow-up year. $0 \mathrm{n}$ this basis we distinguished six sequence clusters of later labour market attachment. 0 ur methodological choice of sequence analysis meant that we were able to employ a larger variety of transitions during the follow-up than has been possible in earlier studies.

Third, we studied the association of types of temporary work with later labour market attachment by comparing the distribution of temporary employee subgroups and permanent employees into these transition clusters. In line with earlier longitudinal research on temporary employment, we found that the majority of temporary employees, in all types of contracts analysed, entered a stable labour market position during the follow-up period, regardless of whether they were employed throughout follow-up, or whether they had a strengthening attachment. On the one hand, for the majority of temporary employees, and for substitute and common fixed-term contract holders in particular, our findings support earlier results pointing at strengthening employment after temporary employment (Booth et al. 2002; G ash 2008; G ebel 2010; Fang and MacPhail 2008; Reichelt 2015; Steijn et al. 2006).

On the other hand, workers in temporary employment positions also had a higher risk of unemployment than employees with permanent contracts. Lending support to the findings of Booth et al. (2002) and to our earlier findings for Finland (Ojala et al. 2015), our results indicated that temporary work, and periphery-type temporary work in particular, is associated with an overall higher risk of unemployment. Furthermore, we found that temporary peripheral employment involves a clear risk of being edged out of the labour market, through heterogeneous paths. We can conclude, then, that people in a severely peripheral position in secondary labour segments are more likely to be excluded 
from the labour market. For some, periphery temporary employment is part of a vicious circle that includes several disadvantaged positions and ends up in exclusion. Highly skilled temps with common fixed-term contracts also had an increased risk of unemployment, but they did not belong to the clusters of weakening attachment or disability pension more often than permanent contract-holding employees. Neither did substitute temporary workers: their risk of entering the unemployment sequence cluster disappeared after controlling for several demographic and job-related issues.

How can both strengthening and weakening paths emerge at the same time, then? Because different people enter more stable, as opposed to more unstable employment. Earlier analyses have shown that the process of integration for non-standard employees usually takes socially divergent paths (Schmid 2008).

We assume that there are both individual, job and labour market related reasons behind this. In line with the results of Aronsson et al. (2002) and Booth et al. (2002), we found that there are groups of more advanced temporary employees and disadvantaged temporary employees. It is known that highlyskilled project workers have better quality jobs. Job quality is a good indicator of labour market position, regardless of whether employees belong to the 'core' or 'periphery' segment (Barbieri 2009; Cutuli and G uetto 2012; G ash 2008; G ebel 2010; Reichelt 2015).

The lower educated and those with previous unemployment in particular will face a higher risk of transition into unemployment. At the individual level, low education and earlier unemployment are interwoven with fragmented careers (de Vries and Wolbers 2005; Gash 2008; Steijn et al. 2006). Health issues also come into play. Dawson et al. (2015) have found that deteriorating mental health among permanent employees is connected with their transition to temporary employment. Wagenaar et al. (2012) found downward employment trajectories if employees had lower health at the baseline. Liukkonen (2012) has stressed the importance of social capital and sense of coherence to avoiding negative transitions. Furthermore, lower skills acquisition is related to the outcomes of short-term contracts (Booth et al. 2002; de Vries \& Wolbers 2005; G ebel 2010; Keep and James 2012) as well as increased work-family conflict, economic disadvantage and decreased well-being (Scherer 2009).

Besides individual level reasons, job and labour market related reasons are crucial. Recent discussions on job polarisation in connection with the economic crisis in Europe expect to see a further deepening of segmentation and downward rather than upward mobility for the middle segment of the labour force, a tendency that will be further strengthened by digitalisation. Even if macro-level analyses show no consistent findings of segmentation or polarisation in comparisons of different periods and countries (see Eurofound 2013), micro-level analysis does indicate tendencies of polarisation at both individual, household, organisational and societal levels (see Kalleberg 2012; Horemans 2016 for discussion). The ongoing restructuring of the labour market in Finland has come at a cost to employees. The numbers working in the industrial sector in particular have fallen significantly since the 1990s. Furthermore, the labour market is regionally segmented: the biggest cities in the southern and southwestern parts of the country are active labour market areas, while large parts of the rest of the country are struggling with declining labour market dynamics. In response to the growth of global completion, the Finnish government is following the same path as many other western countries (Elia 2010; Kalleberg 2012) and seeking to reduce employment costs and security, making the most vulnerable even more vulnerable. 
We call for more research on the connections between heterogeneous employment types, job quality, long-term labour market position (e.g. G ash 2008; Reichelt 2015) and employee well-being (Kompier et al. 2009; Scherer 2009). It would be particularly important to identify factors that can help to slow or halt the process of slipping out of the labour market, whether in terms of improved job quality through increased skills, autonomy or support from managers at the organisational level (Liukkonen 2012), or through improved social security at the societal and labour law level. In the most peripheral types of employment, health care is essential (K alleberg 2012). In Finland, those who are employed have access to private, employer-provided health care. The unemployed do not. In case of discontinuous employment, people have to switch between health care providers. This difficulty may be one reason behind the obvious exclusion from the labour market: people in precarious positions fall between the safety nets that are supposed to help them.

This study setting presented some challenges that require new approaches and further research. The first limitation is related to the study design and information on contract type. The participants' contract type is known only for the survey year, but not during the follow-up. Therefore, we do not have information about the total (accumulated) exposure to different types of temporary work. It follows that we cannot monitor the transition from temporary to permanent employment during the follow-up period. Secondly, the number of most peripheral groups of temporary workers (e.g. agency workers) was too low, and we had to combine them into larger subgroups. Given the gendered nature of temporary employment, it would have been important to analyse men's and women's employment patterns separately. The age of employees, as well as their educational level, may also make a difference. In our model, we adjusted for these factors, but due to the relatively low number of employees with periphery temporary contracts, as well as some of the sequence clusters, we were unable to present separate analyses by gender, age or education groups. Therefore, further studies are needed with larger samples. A major strength of the surveys used, then, is that they constitute a representative populationlevel study that enables comparisons of permanent and temporary workers' positions at a generalisable level, plus the register data covers a relatively long period.

As a policy implication, we suggest that active labour market policies (ALMPs) should be put in place to support employees in peripheral labour market positions. These employees face continuous job insecurity, have a higher risk of unemployment and are easily laid off in case of restructuring or economic turbulence. Most ALMPs focus on unemployment. Employees in insecure positions could be supported before they are made redundant. One way of organising ALMPs may be increased vocational on-the-job training with clear targets of re-employment and increased wages at the end; other nontargeted training for the unemployed has more limited impact (Keep and James 2012).

Changes are also needed to social security. Employees with short contracts are practically selfemployed, in a position of dependent employment (Marchington et al. 2005), facing insecurity (Saloniemi and Z eytinoglu 2007) and several negative work-family outcomes (Scherer 2009). They are under constant pressure to seek for a new job and satisfying income. 0 ur results indicate that a peripheral labour market position presents a serious risk of dropping out of the labour market too early, through early retirement, or in the worst case through disability. Here we agree with Kalleberg (2012), who calls for government action to move towards a 'new social contract', including not only increased employment security but also incentives for employers to add social factors to their employment procedures and understand them as investments instead of costs. 
O verall, our results indicate that type of temporary work is associated with later labour market attachment. Although the majority of temporary workers have a more or less stable employment trajectory, periphery temporary workers in particular have a higher risk of unemployment or labour market exit. Therefore, measures are needed to support periphery temporary workers in particular.

\section{Acknowledgements}

The Academy of Finland (grant 277376) and the Finnish Work Environment Fund (grant 112312) supported this study.

\section{References}

Abbott, A. (1995). Sequence Analysis: New Methods for Old Ideas. A nnual Review of Sociology, 21, 93113.

Aisenbrey, S. \& Fasang, A. (2010). New Life for Old Ideas: The "Second Wave" of Sequence Analysis. Bringing the "Course" Back Into the Life Course. Sociological M ethods \& Research, 38(3), 420-462.

Aronsson, G., G ustafsson, K. \& Dallner, M. (2002). Work environment and health in different types of temporary jobs. E uropean Journal of W ork and Organizational Psychology, 11(2), 151-175.

Barbieri, P. (2009). Flexible Employment and Inequality in Europe. E uropean Sociological Review, 25(6), 621-628.

Biemann, T. \& D atta, D . K. (2014). Analyzing Sequence Data. Optimal Matching in Management Research. 0 rganizational Research M ethods, 17(1), 51-76.

Booth, A.L., Francestoni, M. \& Frank, J. (2002). Temporary jobs: Stepping Stones or D ead ends? The E conomic Journal, 112(480), 189-213.

Broschak, J. P., D avis-Blake, A. \& Block, E. S. (2008). Nonstandard, Not Substandard: The Relationship Among Work Arrangements, Work Attitudes, and Job Performance. W ork and 0 coupations, 35(1), 3-43.

Brzinsky-Fay, C., Kohler, U. \& Luniak, M. (2006). Sequence analysis with Stata. The Stata Journal, 6(4), $435-460$.

Cutuli, G. \& G uetto, R. (2012). Fixed-Term Contracts, Economic Conjuncture, and Training O pportunities: A Comparative Analysis Across European Labour Markets. E uropean Sociological R eview, 29(3), 616-629.

D awson, C., Veliziotis, M., Pacheco, G . \& Webber, D . J. (2015). Is temporary employment a cause or consequence of poor mental health? A panel data analysis. Social Science and M edicine, 134, 50-58.

de Vries, M. R. \& Wolbers, M. H. J. (2005). Non-standard employment relations and wages among school leavers in the Netherlands. W ork, E mployment and Society, 19(3), 503-525.

Elia, L. (2010). Temporary/ permanent workers' wage gap: A brand-new form of wage inequality? L abour, 24(2), 178-200. 
Eurofound (2013). E mployment polarisation and job quality in the crisis: E uropean Jobs M onitor 2013. Dublin, Eurofound.

Eurostat (2016) Temporary employees as percentage of the total number of employees, by sex, age and country of birth (\%), 1995-2015. Eurostat D ata Explorer. Ec.europa.eu. Accessed: 27 ${ }^{\text {th }}$ June 2016.

Fang, T. \& MacPhail, F. (2008). Transitions from Temporary to Permanent Work in Canada: Who Makes the Transition and Why? Social Indicators Research, 88(1), 51-74.

Fervers, L. \& Schwander, H. (2015). Are outsiders equally out everywhere? The economic disadvantage of outsiders in cross-national perspective. E uropean Journal of Industrial Relations, 21(4), 369-387.

Fuller, S. \& Stecy-Hildebrandt, N. (2014). Lasting D isadvantage? Comparing Career Trajectories of Matched Temporary and Permanent Workers in Canada. C anadian Review of Sociology, 51(4), 293-324.

Fuller, S. \& Vosko, L. F. (2008). Temporary Employment and Social Inequality in Canada: Exploring Intersections of Gender, Race and Immigration Status. Social Indicators Research, 88(1), 31-50.

Gash, V. (2008). Bridge or Trap? Temporary Workers' Transitions to Unemployment and to the Standard Employment Contract. E uropeen Sociological Review, 24(5), 651-668.

G authier, J.-A., Widmer, E.D ., Bucher, P. \& Notredame, C. (2010). Multichannel Sequence Analysis Applied to Social Science D ata. Sociological M ethodology, 40(1), 1-38.

G ebel, M. (2010). Early Career Consequences of Temporary Employment in Germany and the UK. W ork, E mployment and Society, 24(4), 641-660.

Horemans, J. (2016). Polarisation of Non-standard Employment in Europe: Exploring a Missing Piece of the Inequality Puzzle. Social Indicators Research, 125(1), 171-189.

Kahn, L. (2016). The Structure of the Permanent Job Wage Premium: Evidence from Europe. Industrial Relations, 55(1), 149-178.

Kalleberg, A. (2012). Job Q uality and Precarious Work: Clarifications, Controversies, and Challenges. W ork and 0 coupations, 39(4), 427-448

Kaufman, L. \& Rousseeuw P. J. (1990). Finding groups in data. an introduction to duster analysis. Wiley, New York.

Kauhanen, M. \& Nätti, J. (2014). Involuntary Temporary and Part-Time Work, Job Q uality and WellBeing at Work. Social Indicators Research, 120(3), 783-799.

Keep, E. \& James, S. (2012). Are Skills the Answer to Bad Jobs? Incentives to Learn at the Bottom End of the Labour Market. In Warhurst, C., Carré, F., Findlay, P. \& Tilly, C. (Eds.) A re Bad Jobs Inevitable? Trends, D eterminants and Responses to Job Q uality in the T wenty-F irst C entury. Basingstoke, Palgrave Macmillan, 240- 253.

Kompier, M., YbemaJ. F., Janssen, J. \& Taris, T. (2009). Employment contracts: Crosssectional and longitudinal relations with quality of working life, health and wellbeing. Journal of 0 coupational $\mathrm{H}$ ealth, 51 , 193-203.

Kyyrä, T. (2008). Partial unemployment insurance benefits and the transition rate to regular work. VATT D iscussion papers 440. Helsinki, G overnment Institute for Economic Research. http:/ / www.vatt.fi/ file/ vatt_publication_pdf/ k440.pdf. Accessed 15 ${ }^{\text {th }}$ July 2016. 
Liukkonen, V. (2012). N on-standard E mployment and H ealth with Respect to Sense of Coherence and Social Capital. Tampere: University of Tampere.

Marchington, M., G rimshaw, D., Rubery, J. \& Willmott, H. (eds) (2005). F ragmenting W ork: Blurring $O$ rganizational Boundaries and D isordering $\mathrm{H}$ ierarchies. Oxford: O xford University Press.

O fficial Statistics of Finland (OSF). Labour force survey [e-publication]. Employment and unemployment in 2015. Helsinki: Statistics Finland.

http:// www.stat.fi/ til/ tyti/ 2015/13/ tyti_2015 13 2016-04-12 kat 002 en.html. Accessed 17th November 2016.

Ojala, S., Nätti, J. \& Kauhanen, M. (2015). Työn laatu ja myöhempi työura osa- ja määräaikaisessa työssä. [Job quality and later work career among part-time and temporary employees.] Tampere, University of Tampere. http:// tampub.uta.fi/ handle/ 10024/97990. A ccessed 28th February 2017.

Reichelt, M. (2015). Career Progression from Temporary Employment: How Bridge and Trap Functions Differ by Task Complexity. E uropean Sociological Review, 31(5), 558-572.

Repo, K. (2010). Finnish child home care allowance - users' perspectives and perceptions. In: J. Sipilä, J., Repo, K. \& Rissanen, T. (Eds.). C ash-for-C hildcare. The C onsequenos for C aring M others. Cheltenham: Edward Elgar.

Saloniemi, A. \& Zeytinoglu, I. U. (2007). Achieving Flexibility through Insecurity: A Comparison of Work Environments in Fixed-term and Permanent Jobs in Finland and Canada. E uropean Journal of Industrial R elations, 13(1), 109-128.

Scherer, S. (2009). The Social Consequences of Insecure Jobs. Social Indicators Research, 93(3), 527-547.

Schmid, G . (2008). F ull E mployment in E urope. M anaging L abour M ark et T ransitions and Risks. Cheltenham: Edward Elgar.

Steijn, B., Need, A. \& G esthuizen, M. (2006). Well begun, half done? Long-term effects of labour market entry in the Netherlands, 1950-2000. W ork, employment and society, 20(3), 453-472.

Studer, M., Ritschard, G., Gabadinho, A. \& Müller,N. S. (2011). D iscrepancy analysis of state sequences. Sociol. Meth. Res., 40, 471-510.

Sutela, H. \& Lehto, A.-M. (2014) Työolojen muutok set 1977- 2013. [Changes in Working Conditions 19772013.] Helsinki, Statistics Finland.

Wagenaar, A., Kompier, M., Houtman, I., van den Bossche, S. \& Taris, T. (2012). Employment Contracts and Health Selection. Unhealthy Employees O ut and Healthy Employees In? J0 E M, 54(10), 1192-1200. 


\begin{tabular}{|c|c|c|c|c|c|}
\hline \multirow[t]{2}{*}{ Temporary contract type } & \multirow{2}{*}{$\begin{array}{c}1990 \\
\\
\%\end{array}$} & \multirow{2}{*}{$\begin{array}{c}1997 \\
\% \\
\end{array}$} & \multirow{2}{*}{$\begin{array}{c}2003 \\
\%\end{array}$} & \multicolumn{2}{|c|}{$\begin{array}{c}\text { Total } \\
\text { 1990- } 2003\end{array}$} \\
\hline & & & & $\mathbf{N}$ & $\%$ \\
\hline Substitute (1) & 3,1 & 4,5 & 4,6 & 377 & 4,1 \\
\hline $\begin{array}{l}\text { Common fixed-term (including other fixed- } \\
\text { term, on a trial period, in apprenticeship } \\
\text { training) (2) }\end{array}$ & 9,0 & 8,6 & 7,8 & 780 & 8,4 \\
\hline $\begin{array}{l}\text { Periphery (including seasonal, on-call, } \\
\text { temporary agency and employment subsidy } \\
\text { workers) (3) }\end{array}$ & 1,4 & 5,3 & 2,6 & 275 & 3,0 \\
\hline Total permanent work (4) & 86,5 & 81,7 & 85,0 & 7823 & 84,5 \\
\hline T otal all employees & $100, n=3134$ & $100, n=2703$ & $100, n=3418$ & 9255 & 100 \\
\hline
\end{tabular}

Table 1. Contract types of employees aged 20-54 according to year of survey, FQWLS 1990, 1997 and 2003 


\begin{tabular}{|c|c|c|c|c|c|c|c|c|c|c|c|c|c|c|c|}
\hline & $\begin{array}{l}\text { Proportion } \\
\text { of women } \\
\text { (\%) }\end{array}$ & $\begin{array}{l}\text { Proportion } \\
\text { of having a } \\
\text { child (\%) }\end{array}$ & $\begin{array}{l}\text { Proportion } \\
\text { getting a } \\
\text { baby (\%) }\end{array}$ & $\begin{array}{l}\text { Proportio } \\
\text { n of } \\
\text { public } \\
\text { sector (\%) }\end{array}$ & $\begin{array}{l}\text { Proportion } \\
\text { of young } \\
\text { (<33 yrs.) }\end{array}$ & $\begin{array}{l}\text { Proportion } \\
\text { of tertiary } \\
\text { educated } \\
(\%)\end{array}$ & $\begin{array}{l}\text { Propontio } \\
\text { n of } \\
\text { students } \\
(\%)\end{array}$ & $\begin{array}{l}\text { Contract } \\
\text { duration } \\
\text { (Years) }\end{array}$ & \begin{tabular}{|l|} 
Proportion \\
of previous \\
unempl. \\
$(\%)$
\end{tabular} & \begin{tabular}{|l|} 
Mean \\
employed \\
months in \\
year -1 \\
(Months)
\end{tabular} & $\begin{array}{l}\text { Propontio } \\
\text { n of long- } \\
\text { term } \\
\text { illness } \\
(\%)\end{array}$ & $\begin{array}{l}\text { Proponti } \\
\text { on of } \\
\text { those } \\
\text { living in } \\
\text { rural } \\
\text { area } \\
(\%)\end{array}$ & $\begin{array}{l}\text { Mean } \\
\text { wage } \\
\text { (Standa } \\
\text { rdised) }\end{array}$ & $\begin{array}{l}\text { Mean } \\
\text { on-the- } \\
\text { job } \\
\text { training } \\
\text { (Days } \\
\text { / Year) }\end{array}$ & $\begin{array}{l}\text { Proportio } \\
\text { n of } \\
\text { under } \\
\text { threat/ s } \\
\text { (\%) }\end{array}$ \\
\hline $\begin{array}{l}\text { Substitute } \\
\text { (1) }\end{array}$ & $83^{T}$ & $43^{A T}$ & $37^{T}$ & $74^{T}$ & $57^{T}$ & 33 & $11^{T}$ & 1,7 & $59^{T}$ & 7,5 & $19^{A T}$ & $49^{T}$ & $-0,33$ & 2,2 & $59^{T}$ \\
\hline $\begin{array}{l}\text { Common } \\
\text { fixed-term } \\
\text { (2) }\end{array}$ & $57^{T}$ & $39^{A T}$ & $34^{T}$ & $52^{T}$ & $55^{T}$ & 30 & $21^{T}$ & 1,6 & $53^{T}$ & 7,7 & $22^{A T}$ & $52^{T}$ & $-0,45$ & 1,6 & $48^{T}$ \\
\hline $\begin{array}{l}\text { Periphery } \\
\text { (3) }\end{array}$ & 57 & $39^{A T}$ & 18 & $46^{T}$ & $45^{T}$ & 11 & 9 & 0,8 & $85^{T}$ & 5,5 & $31^{T}$ & $63^{T}$ & $-0,85$ & 1,1 & $70^{T}$ \\
\hline $\begin{array}{l}\text { Permanent } \\
\text { contract (4) }\end{array}$ & $50^{A T}$ & $50^{T}$ & $20^{T}$ & $33^{A T}$ & $28^{A T}$ & 25 & $5^{A T}$ & 9,8 & $18^{A T}$ & 11,0 & $25^{T}$ & $40^{A T}$ & 0,09 & 3,3 & $20^{A T}$ \\
\hline $\begin{array}{l}\text { Total All } \\
\text { employees }\end{array}$ & 52 & 48 & 22 & 37 & 32 & 26 & 6 & 8,5 & 25 & 10,4 & 25 & 42 & 0 & 3,1 & 25 \\
\hline Sig. / F & $* * *$ & $* * *$ & *** & $* * *$ & $* * *$ & $1,2>4>3$ & $* * *$ & $4>1,2>3$ & $* * *$ & $4>1,2>3$ & $* * *$ & $* * *$ & $4>1,2>3$ & $4>1,2>3$ & $* * *$ \\
\hline
\end{tabular}

Chi Sq* $\mathrm{p}<.05 ; * * \mathrm{p}<.01$; *** $\mathrm{p} \leq .001$, D unnett T3: O nly significant pairwise comparisons are reported $(\mathrm{p}<.05)$. ${ }^{T}$ more typical than on average and ${ }^{A T}$ less typical than on average (adjusted residual $>|2.0|$ ).

Table 2. Descriptives of temporary employees' subgroups by background factors, FQWLS 1990, 1997 and 2003 
I Stable employment, $78 \%$

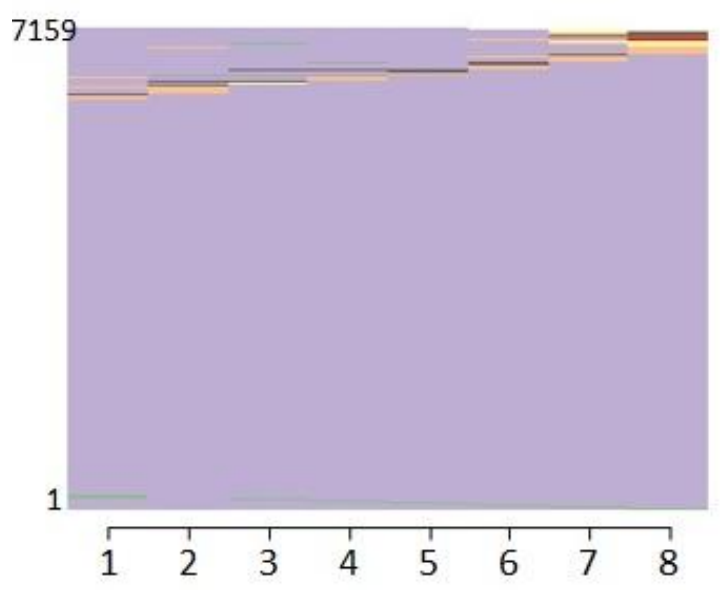

IV High unemployment, $6 \%$

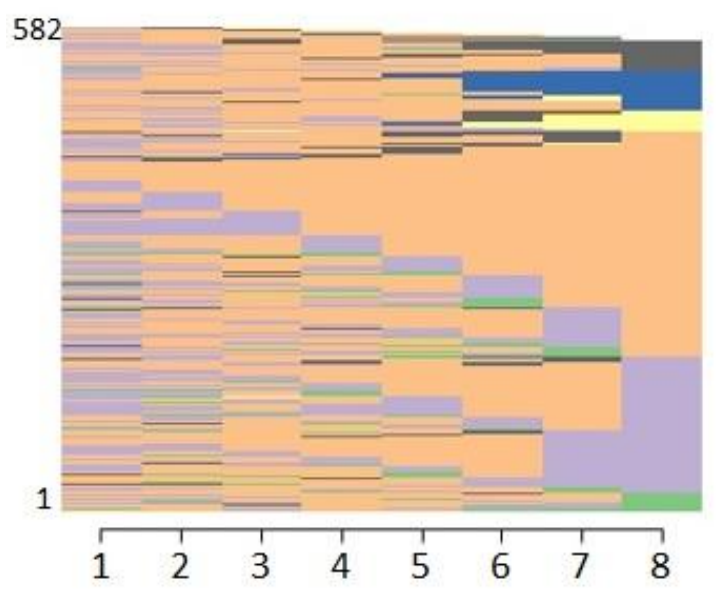

II Out of labour market, $2 \%$

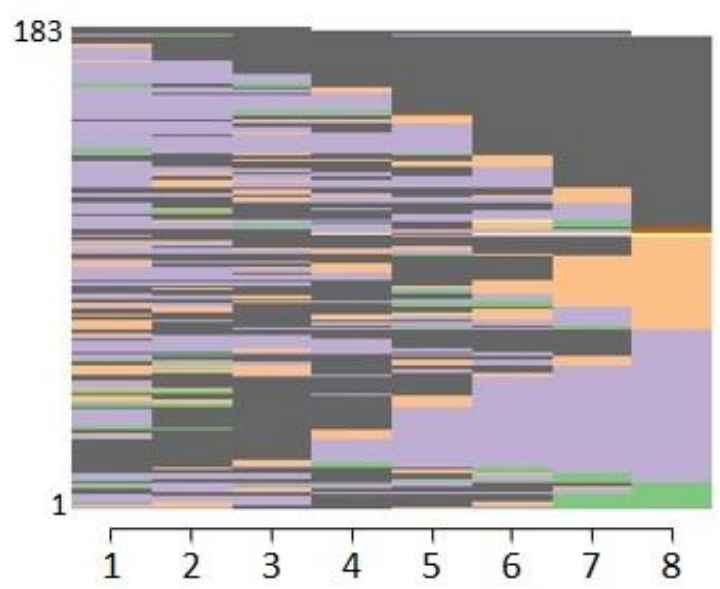

$\checkmark$ Weakening attachment, $5 \%$

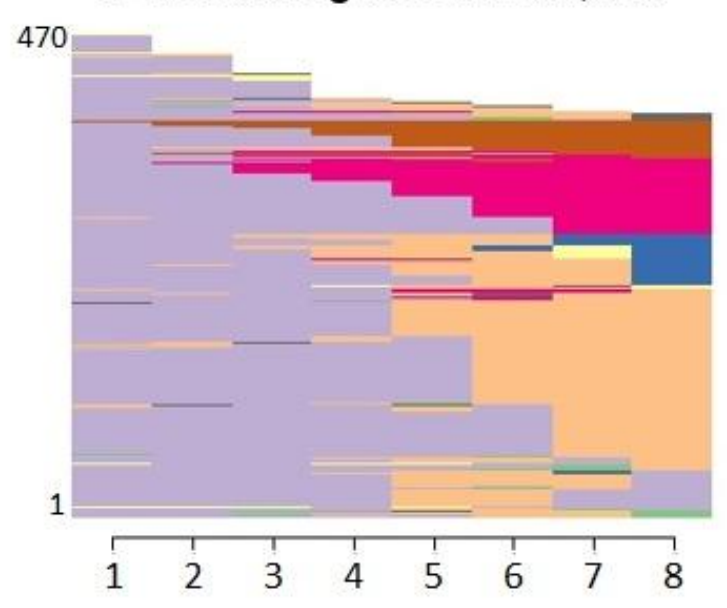

III Strengthening attachment, $7 \%$

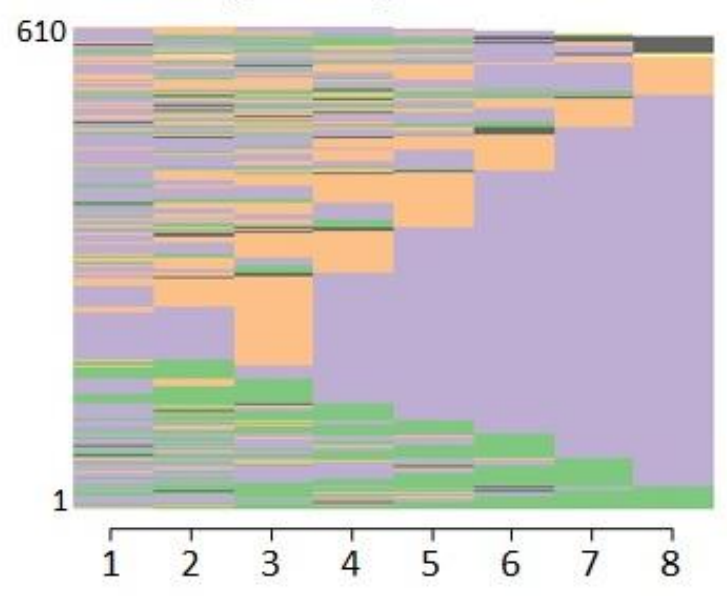

VI Disability pension, $3 \%$

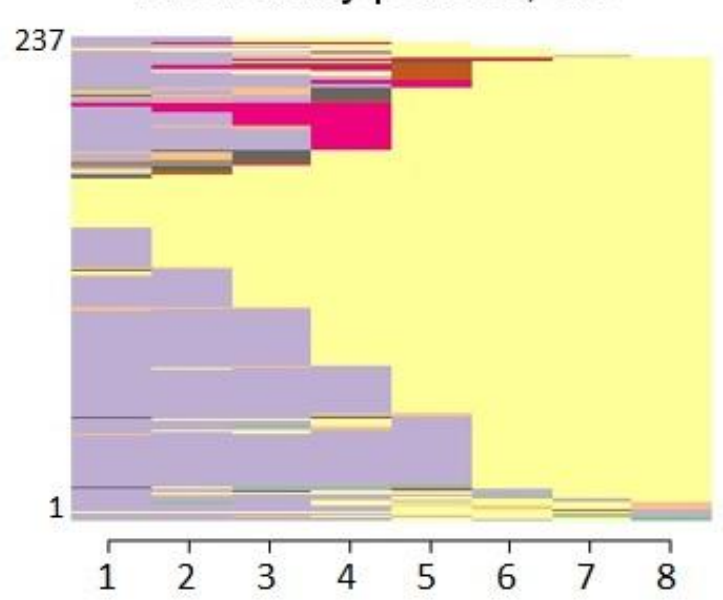

\begin{tabular}{|lll|}
\hline$\square$ Student & $\square$ Disability pension & $\square$ Old age pension \\
$\square$ Employed & $\square$ Unemployment pension & $\square$ Other activity \\
$\square$ Unemployed & $\square$ Other early pension & \\
\hline
\end{tabular}

Figure 1. Sequence clusters of yearly statuses of Finnish employed populations, FQ WLS 1990, 1997, 2003 + registers 8 yrs 


\begin{tabular}{|c|c|c|c|c|c|c|c|c|c|}
\hline & \multicolumn{3}{|c|}{ Temporary contract type } & \multirow{2}{*}{$\begin{array}{l}\text { Permanent } \\
\text { contract } \\
\text { (4) }\end{array}$} & \multirow{2}{*}{$\begin{array}{c}\text { All } \\
\text { employees } \\
\text { Total }\end{array}$} & \multirow[t]{2}{*}{ Dunnett T 3} & \multirow{2}{*}{$\begin{array}{l}\text { Proportion } \\
\text { of women }\end{array}$} & \multirow[t]{2}{*}{ Mean age } & \multirow{2}{*}{$\begin{array}{l}\text { Proportion } \\
\text { of tertiary } \\
\text { educated }\end{array}$} \\
\hline & $\begin{array}{l}\text { Substi- } \\
\text { tute (1) }\end{array}$ & $\begin{array}{c}\text { Common } \\
\text { fixed-tem (2) }\end{array}$ & $\begin{array}{l}\text { Periphery } \\
\text { (3) }\end{array}$ & & & & & & \\
\hline $\begin{array}{l}\text { Cluster I Stable } \\
\text { employment }\end{array}$ & $70 \%$ & $64 \%$ & $40 \%$ & $81 \%$ & $78 \%$ & $4>1,2>3$ & $52 \%$ & 38 & $29 \%$ \\
\hline $\begin{array}{l}\text { Cluster II Out of } \\
\text { labour market }\end{array}$ & $5 \%$ & $3 \%$ & $4 \%$ & $2 \%$ & $2 \%$ & $1>4$ & $76 \%$ & 32 & $19 \%$ \\
\hline $\begin{array}{l}\text { Cluster III } \\
\text { Strengthening } \\
\text { attachment }\end{array}$ & $14 \%$ & $16 \%$ & $16 \%$ & $5 \%$ & $7 \%$ & $1,2,3>4$ & $55 \%$ & 32 & $13 \%$ \\
\hline $\begin{array}{l}\text { Cluster IV High } \\
\text { unemployment }\end{array}$ & $8 \%$ & $11 \%$ & $29 \%$ & $5 \%$ & $6 \%$ & $3>1,3>2>4$ & $45 \%$ & 39 & $7 \%$ \\
\hline $\begin{array}{l}\text { Cluster V } \\
\text { Weakening } \\
\text { attachment }\end{array}$ & $2 \%$ & $4 \%$ & $7 \%$ & $5 \%$ & $5 \%$ & $4>1$ & $49 \%$ & 46 & $17 \%$ \\
\hline $\begin{array}{l}\text { Cluster VI } \\
\text { Disability pension }\end{array}$ & $1 \%$ & $2 \%$ & $4 \%$ & $3 \%$ & $3 \%$ & $3>1,4>1$ & $49 \%$ & 47 & $9 \%$ \\
\hline Total & $100 \%$ & $100 \%$ & $100 \%$ & $100 \%$ & $100 \%$ & & $52 \%$ & 38 & $26 \%$ \\
\hline $\mathbf{N}$ & 377 & 779 & 274 & 7811 & 9241 & & & & \\
\hline
\end{tabular}

D unnett T3: Only significant pairwise comparisons are reported $(\mathrm{p}<.05)$.

Table 3. Breakdown of temporary workers' subgroups into employment clusters, FQWLS 1990, 1997, 2003 + registers 8 yrs 


\begin{tabular}{|c|c|c|c|c|c|c|c|c|c|c|c|c|c|c|c|c|}
\hline & \multirow{2}{*}{$\begin{array}{l}\begin{array}{l}\text { I: Stable } \\
\text { employment } \\
\text { (n=7,159) }\end{array} \\
\text { Ref. }\end{array}$} & \multicolumn{3}{|c|}{$\begin{array}{l}\text { II: Out of labour } \\
\text { market }(n=183)\end{array}$} & \multicolumn{3}{|c|}{$\begin{array}{l}\text { III: Strengthening } \\
\text { attachment }(n=610)\end{array}$} & \multicolumn{3}{|c|}{$\begin{array}{l}\text { IV: High unemployment } \\
(n=582)\end{array}$} & \multicolumn{3}{|c|}{$\begin{array}{l}\text { V: Weakening } \\
\text { attachment }(n=470)\end{array}$} & \multicolumn{3}{|c|}{$\begin{array}{l}\text { VI: Disability pension } \\
(\mathrm{n}=237)\end{array}$} \\
\hline & & $\operatorname{Exp(B)}$ & $\begin{array}{l}\mathbf{9 5 \%} \\
\text { Lower }\end{array}$ & Upper & $\operatorname{Exp}(\mathrm{B})$ & $\begin{array}{l}\mathbf{9 5 \%} \\
\text { Lower }\end{array}$ & Upper & $\operatorname{Exp(B)}$ & $\begin{array}{l}\mathbf{9 5 \%} \text { C } \\
\text { Lower }\end{array}$ & U. & $\operatorname{Exp(B)}$ & $\begin{array}{l}\mathbf{9 5 \%} \\
\text { Lower }\end{array}$ & $\begin{array}{l}\text { I. } \\
\text { Upper }\end{array}$ & $\operatorname{Exp(B)}$ & $\begin{array}{l}\mathbf{9 5 \%} \text { C } \\
\text { Lower }\end{array}$ & $\begin{array}{l}\text { I. } \\
\text { Upper }\end{array}$ \\
\hline \multicolumn{17}{|c|}{ Model 1: Adjusted for Survey year (1990, 1997, or 2003), ${ }^{*} \mathbf{p}<.05 ;{ }^{* *} p<.01 ; * * * p \leq .001$} \\
\hline Intercept & & $* * *$ & & & *** & & & *** & & & $* * *$ & & & *** & & \\
\hline Substitute & 1 & $3,733^{* * *}$ & 2,24 & 6,23 & $3,824^{* * *}$ & 2,76 & 5,30 & $2,433^{* * *}$ & 1,64 & 3,62 & $0,525 \mathrm{~ns}$ & 0,27 & 1,03 & $0,374 n s$ & 0,12 & 1,18 \\
\hline $\begin{array}{l}\text { Common } \\
\text { fixed-term }\end{array}$ & 1 & $2,686^{* * *}$ & 1,74 & 4,14 & $4,440 * * *$ & 3,54 & 5,57 & $3,189 * * *$ & 2,47 & 4,12 & $0,856 \mathrm{~ns}$ & 0,58 & 1,27 & $0,745 \mathrm{~ns}$ & 0,41 & 1,34 \\
\hline $\begin{array}{l}\text { Periphery } \\
\text { Permanent }\end{array}$ & $\begin{array}{l}1 \\
\text { ref. }\end{array}$ & $\begin{array}{l}6,381 * * * \\
\text { ref. }\end{array}$ & 3,31 & 12,90 & $\begin{array}{l}9,832 * * * \\
\text { ref. }\end{array}$ & 6,74 & 14,34 & $\begin{array}{l}19,549 * * * \\
\text { ref. }\end{array}$ & 14,07 & $\begin{array}{l}27,16 \\
.\end{array}$ & $\begin{array}{l}2,497 * * * \\
\text { ref. }\end{array}$ & 1,50 & 4,17 & $\begin{array}{l}3,782 * * * \\
\text { ref. }\end{array}$ & 2,03 & 7,04 \\
\hline
\end{tabular}

Cox and Snell - Nagelkerke $10,2 \%-12,4 \%$; -2 LL 309; ChiSq (df) Sig. 998 (25) ***; Adjusted for: Year, * p <.05; ** p <.01;** p $\leq .001$

Model 2: Adjusted for Survey year + Gender, Education, Student, $H$ as a child ( $<18$ yrs.), Baby bom during follow-up, Age $<33$, Rural area of living, Experienced unemployment, Long-tem illness, E mployed months one year before survey, Employment contract duration, Employment sector, Employer-provided training, Standardised wage, and Threat of unemployment

\begin{tabular}{|c|c|c|c|c|c|c|c|c|c|c|c|c|c|c|c|c|}
\hline Intercept & & *** & & & **** & & & *** & & & **** & & & **** & & \\
\hline Substitute & 1 & $1,445 \mathrm{~ns}$ & 0,80 & 2,62 & $2,118^{* * *}$ & 1,46 & 3,08 & $1,505 \mathrm{~ns}$ & 0,94 & 2,40 & $1,010 \mathrm{~ns}$ & 0,49 & 2,07 & ,656ns & ,19 & 2,22 \\
\hline $\begin{array}{l}\text { Common } \\
\text { fixed-term }\end{array}$ & 1 & $1,269 \mathrm{~ns}$ & 0,77 & 2,09 & $1,906 * * *$ & 1,45 & 2,51 & $1,721^{* * *}$ & 1,24 & 2,39 & $1,620^{*}$ & 1,04 & 2,53 & $1,457 \mathrm{~ns}$ & ,74 & 2,88 \\
\hline Periphery & 1 & $2,388 *$ & 1,14 & 5,00 & $2,754^{* * *}$ & 1,80 & 4,21 & $4,352^{* * *}$ & 2,91 & 6,51 & $3,312^{* * *}$ & 1,84 & 5,98 & $3,190 * *$ & 1,48 & 6,88 \\
\hline Permanent & ref. & ref. & . & . & ref. & . & . & ref. & . & . & ref. & . & . & ref. & . & \\
\hline
\end{tabular}

Cox and Snell - Nagelkerke

27.6\% - 33.4\%; -2 LL 13092; ChiSq (df) Sig. 2978 (105)***, N=9,255

Table 4. Multinomial logistic regression coefficients by temporary employees' subgroups, dependent variable: employment sequence clusters, FQWLS 1990, 1997, 2003 + registers 8 yrs 
Appendix. Dependent and independent variable comelations.

\begin{tabular}{|c|c|c|c|c|c|c|c|c|c|c|c|c|c|c|c|c|c|c|c|c|c|c|c|c|c|}
\hline Correlations & (1) & (2) & (3) & (4) & (5) & (6) & (7) & (8) & (9) & (10) & (11) & (12) & (13) & (14) & (15) & (16) & (17) & (18) & (19) & (20) & (21) & (22) & (23) & (24) & (25) \\
\hline $\begin{array}{l}1 \text { Cluster I } \\
\text { Emploved }\end{array}$ & 1,00 & & & & & & & & & & & & & & & & & & & & & & & & \\
\hline $\begin{array}{l}2 \text { II Outside } \\
\text { labour market }\end{array}$ & $-0,26$ & 1,00 & & & & & & & & & & & & & & & & & & & & & & & \\
\hline $\begin{array}{l}3 \text { III Tightening } \\
\text { employment }\end{array}$ & $-0,49$ & $-0,04$ & 1,00 & & & & & & & & & & & & & & & & & & & & & & \\
\hline 4 IV High unempl. & $-0,48$ & $-0,04$ & $-0,07$ & 1,00 & & & & & & & & & & & & & & & & & & & & & \\
\hline $\begin{array}{l}5 \mathrm{~V} \text { Weakening } \\
\text { emplovment }\end{array}$ & $-0,43$ & $-0,03$ & $-0,06$ & $-0,06$ & 1,00 & & & & & & & & & & & & & & & & & & & & \\
\hline $\begin{array}{l}6 \text { Cluster VI } \\
\text { Disability pension }\end{array}$ & $-0,30$ & $-0,02$ & $-0,04$ & $-0,04$ & $-0,04$ & 1,00 & & & & & & & & & & & & & & & & & & & \\
\hline $\begin{array}{l}7 \text { Contract: - } \\
\text { permanent }\end{array}$ & 0,17 & $-0,06$ & $-0,15$ & $-0,13$ & 0,02 & 0,02 & 1,00 & & & & & & & & & & & & & & & & & & \\
\hline 8 - substitute & $-0,04$ & 0,04 & 0,06 & 0,02 & $-0,03$ & $-0,02$ & $-0,48$ & 1,00 & & & & & & & & & & & & & & & & & \\
\hline 9- other & $-0,10$ & 0,03 & 0,12 & 0,06 & $-0,02$ & $-0,02$ & $-0,71$ & \begin{tabular}{|c|}
$-0,06$ \\
\end{tabular} & 1,00 & & & & & & & & & & & & & & & & \\
\hline 10 - periphery & $-0,16$ & 0,03 & 0,07 & 0,16 & 0,01 & 0,02 & $-0,41$ & $-0,04$ & $-0,05$ & 1,00 & & & & & & & & & & & & & & & \\
\hline $11 \mathrm{G}$ ender & 0,01 & 0,07 & 0,01 & $-0,04$ & $-0,02$ & $-0,01$ & $-0,10$ & 0,13 & 0,03 & 0,02 & 1,00 & & & & & & & & & & & & & & \\
\hline 12 Education & 0,19 & $-0,02$ & $-0,05$ & $-0,14$ & $-0,07$ & $-0,09$ & $-0,05$ & 0,05 & 0,05 & $-0,04$ & 0,06 & 1,00 & & & & & & & & & & & & & \\
\hline 13 Student & $-0,04$ & 0,01 & 0,15 & $-0,04$ & $-0,03$ & $-0,04$ & $-0,17$ & 0,04 & 0,19 & 0,02 & 0,05 & 0,05 & 1,00 & & & & & & & & & & & & \\
\hline 14 Has a child & 0,13 & 0,00 & $-0,05$ & $-0,06$ & $-0,08$ & $-0,07$ & 0,07 & $-0,02$ & $-0,06$ & $-0,03$ & 0,03 & 0,07 & $-0,09$ & 1,00 & & & & & & & & & & & \\
\hline 15 Baby born & 0,01 & 0,13 & 0,07 & $-0,04$ & $-0,08$ & $-0,08$ & $-0,11$ & 0,08 & 0,09 & $-0,02$ & $-0,02$ & 0,08 & 0,09 & $-0,05$ & 1,00 & & & & & & & & & & \\
\hline $\begin{array}{l}16 \text { Has been } \\
\text { unemployed }\end{array}$ & $-0,16$ & 0,05 & 0,09 & 0,18 & $-0,02$ & $-0,01$ & $-0,35$ & 0,16 & 0,20 & 0,24 & $-0,01$ & $-0,04$ & $-0,01$ & $-0,05$ & 0,09 & 1,00 & & & & & & & & & \\
\hline $\begin{array}{l}17 \text { Long-term } \\
\text { illness }\end{array}$ & $-0,09$ & $-0,01$ & $-0,01$ & 0,02 & 0,04 & 0,16 & 0,02 & $-0,03$ & $-0,02$ & 0,02 & 0,02 & $-0,06$ & $-0,03$ & $-0,04$ & $-0,07$ & $-0,01$ & 1,00 & & & & & & & & \\
\hline $\begin{array}{l}18 \text { Living area in } \\
\text { Finland }\end{array}$ & 0,05 & 0,02 & $-0,02$ & $-0,08$ & 0,01 & $-0,02$ & 0,10 & $-0,03$ & $-0,06$ & $-0,08$ & 0,03 & 0,02 & 0,03 & $-0,04$ & 0,01 & $-0,09$ & $-0,04$ & 1,00 & & & & & & & \\
\hline 19 Empl. sector & $-0,09$ & 0,01 & 0,06 & 0,07 & 0,02 & $-0,01$ & 0,18 & $-0,16$ & $-0,10$ & $-0,04$ & $-0,23$ & $-0,17$ & $-0,01$ & $-0,05$ & 0,06 & 0,05 & $-0,04$ & 0,09 & 1,00 & & & & & & \\
\hline $\begin{array}{l}20 \text { Empl. months } \\
\text { vear-1 }\end{array}$ & 0,15 & $-0,07$ & $-0,14$ & $-0,12$ & 0,03 & 0,02 & 0,40 & $-0,18$ & $-0,24$ & $-0,25$ & $-0,08$ & $-0,05$ & $-0,16$ & 0,07 & $-0,10$ & $-0,28$ & 0,01 & 0,06 & 0,12 & 1,00 & & & & & \\
\hline 21 Age < 33 yrs. & $-0,03$ & 0,09 & 0,15 & $-0,01$ & $-0,09$ & $-0,09$ & $-0,20$ & 0,11 & 0,15 & 0,05 & $-0,04$ & 0,04 & 0,21 & $-0,23$ & 0,50 & 0,19 & $-0,12$ & 0,01 & 0,12 & $-0,21$ & 1,00 & & & & \\
\hline $\begin{array}{l}22 \text { Contract } \\
\text { duration }\end{array}$ & 0,05 & $-0,08$ & $-0,15$ & $-0,08$ & 0,14 & 0,10 & 0,35 & $-0,16$ & $-0,25$ & $-0,16$ & $-0,03$ & $-0,13$ & $-0,16$ & 0,01 & $-0,29$ & $-0,36$ & 0,12 & $-0,02$ & $-0,08$ & 0,30 & $-0,45$ & 1,00 & & & \\
\hline $\begin{array}{l}23 \text { On-the-job } \\
\text { training }\end{array}$ & 0,11 & $-0,03$ & $-0,05$ & $-0,09$ & $-0,02$ & $-0,03$ & 0,09 & $-0,05$ & $-0,04$ & $-0,08$ & $-0,02$ & 0,17 & 0,05 & 0,04 & $-0,01$ & $-0,12$ & $-0,03$ & 0,03 & $-0,07$ & 0,10 & $-0,04$ & 0,03 & 1,00 & & \\
\hline 24 Wage & 0,16 & $-0,06$ & $-0,11$ & $-0,11$ & 0,01 & $-0,04$ & 0,21 & $-0,09$ & $-0,11$ & $-0,16$ & $-0,32$ & 0,35 & $-0,08$ & 0,11 & $-0,06$ & $-0,24$ & $-0,06$ & 0,13 & 0,05 & 0,20 & $-0,21$ & 0,18 & 0,26 & 1,00 & \\
\hline $\begin{array}{l}25 \text { Threat of } \\
\text { unempl. }\end{array}$ & $-0,13$ & 0,01 & 0,04 & 0,15 & 0,02 & 0,01 & $-0,24$ & 0,14 & 0,12 & 0,15 & $-0,02$ & $-0,01$ & $-0,04$ & $-0,01$ & $-0,01$ & 0,26 & 0,03 & $-0,06$ & 0,04 & $-0,09$ & $-0,01$ & $-0,07$ & $-0,08$ & $-0,07$ & 1,00 \\
\hline 26 Survey year & 0,19 & $-0,03$ & $-0,13$ & $-0,14$ & 0,00 & $-0,04$ & $-0,02$ & 0,03 & $-0,02$ & 0,03 & 0,01 & 0,25 & $-0,10$ & $-0,02$ & $-0,04$ & 0,09 & 0,06 & 0,01 & $-0,01$ & 0,00 & $-0,07$ & 0,01 & 0,00 & 0,00 & 0,10 \\
\hline
\end{tabular}

